Sains Malaysiana 50(8)(2021): 2395-2405

http://doi.org/10.17576/jsm-2021-5008-21

\title{
Physicochemical Properties of MoVTeNb Mixed Oxide Catalysts Synthesized using Different Vanadium Sources
}

(Sifat Fizikokimia Pemangkin Pencampuran Oksida MoVTeNb Dihasilkan dengan Punca Vanadium yang Berbeza)

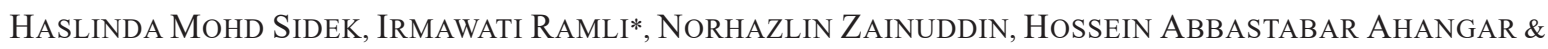 \\ TAUFIQ-YAP YUN HIN
}

\begin{abstract}
The use of different vanadium sources in the synthesis of multi-metal MoVTeNb oxide catalysts has been investigated for their effect on the physicochemical properties of catalysts. Metal oxides were synthesized by slurry method assisted with a microwave irradiation. Vanadium pentoxide $\left(\mathrm{V}_{2} \mathrm{O}_{5}\right)$, vanadyl sulphate (VOSO $)$ and ammonium metavanadate $\left(\mathrm{NH}_{4} \mathrm{VO}_{3}\right)$ were used as the vanadium sources, respectively. X-ray diffraction (XRD) pattern showed the existence of orthorhombic (M1) phases in all catalysts. The catalyst prepared using $V_{2} \mathrm{O}_{5}$ produced the highest formation of the phase. This was further supported by Inductive Couple Plasma-Atomic Emission Spectroscopy (ICP-AES), which showed that the $\mathrm{V}_{2} \mathrm{O}_{5}$ catalyst has the highest $\mathrm{V}$ : Mo ratio, mainly responsible for the high catalytic activity. Temperature Programmed Reduction in Hydrogen $\left(H_{2}\right.$-TPR) showed better reducibility for the catalyst when compared to the others. Temperature Programmed Reaction (TPRn) confirmed that the oxidants active for propane conversion into acrylic acid were originated from the lattice of the catalyst.
\end{abstract}

Keywords: Acrylic acid; anaerobic reaction; MoVTeNb mixed metal oxide; propane oxidation; vanadium source

\section{ABSTRAK}

Penggunaan punca vanadium yang berlainan dalam sintesis pemangkin oksida berbilang logam MoVTeNb telah dikaji kesannya terhadap sifat fizikokimia mangkin. Logam oksida disintesis dengan kaedah buburan berbantu radiasi

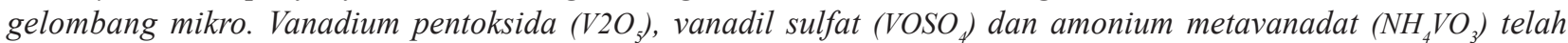
digunakan sebagai punca vanadium. Corak pembelauan sinar-X (XRD) mendedahkan kewujudan fasa ortorombik (M1) pada semua sampel. Sampel yang disediakan menggunakan $V_{2} \mathrm{O}_{5}$ menghasilkan pembentukan fasa tersebut yang tertinggi. Ini disokong oleh Plasma Gandingan Aruhan-Spektroskopi Pancaran Atom (ICP-AES), yang menunjukkan bahawa mangkin $V_{2} \mathrm{O}_{5}$ mempunyai nisbah $V$ : Mo tertinggi, kerana ia bertanggungjawab untuk meningkatkan aktiviti pemangkinan. Penurunan Suhu Berprogram Hidrogen $\left(H_{2}-T P R\right)$ menunjukkan sifat kebolehturunan yang lebih baik untuk mangkin ini berbanding dengan yang lain. Tindak Balas Suhu yang Diprogramkan (TPRn) mengesahkan bahawa oksidan aktif bagi penukaran propana kepada asid akrilik berasal daripada kekisi mangkin.

Kata kunci: Asid akrilik; logam oksida campuran MoVTeNb; pengoksidaan propana; punca vanadium; tindak balas anaerobik

\section{INTRODUCTION}

There are abundant resources of lower alkanes present in natural gas and petroleum refinery off-gases. Unfortunately, these resources are usually used for electricity generation in industry and for domestic cooking. Therefore, there is a need to upgrade these alkanes into higher value product, for example by converting the alkanes into petrochemicals (Beato et al. 2006; Irmawati et al. 2011; Wong et al. 2012). Since these alkanes have the potential of being the raw materials for selective oxidation 
into valuable petrochemical products, much effort has been undertaken in order to develop novel catalyst for this reaction. This represents the shift in the technology since current alkene feedstock has been substituted by abundant, lower cost as well as environmentally friendly sources. However, this process must involve the use of a catalyst to activate the stable alkanes for the desired reaction. In the early 1990s, Mitsubishi Chemical Corporation have developed a multicomponent $\mathrm{MoVTeNb}$ oxide catalyst that have unique catalytic properties that contributes to the high efficiency in numerous reactions such as selective oxidation of propane to acrylic acid, ammoxidation of propane to acrylonitrile and oxidative dehydrogenation of ethane to ethylene (Popova et al. 2009a). These catalysts have also been studied in oxidative dehydrogenation of propane, selective oxidation of butane to maleic anhydride and alcoholic oxidation (Botella et al. 2002; Popova et al 2009b).

The activity of the catalyst is apparently achieved when having two main crystalline phases which are orthorhombic (M1) phase and hexagonal (M2) phase. Other traces such as $\left(\mathrm{Mo}_{0.93} \mathrm{~V}_{0.07}\right)_{5} \mathrm{O}_{14}, \mathrm{MoO}_{3}$, and $\mathrm{TeMo}_{5} \mathrm{O}_{16}$ phases might also present depending on the preparation method and activation procedure applied (Florea et al. 2006; Popova et al. 2009b). The structure of M1 phase consists of corner-linked $\mathrm{MO}_{6}$ octahedrons $(\mathrm{M}=\mathrm{Mo}$, $\mathrm{V})$, which are assembled in the (001) plane forming characteristics hexagonal and heptagonal rings, partially hosting Te-O units. As compared to M1 phase, M2 phase only possess hexagonal channels (Beato et al. 2006). AlSaeedi et al. (2003) have reported of the importance of vanadium element on the catalyst characteristics. They stated that vanadia-based catalyst is the most efficient for oxidative catalytic conversion of propane to propylene and oxygenates such as acrolein and acrylic acid. Meanwhile, Guerrero-Perez et al. (2004) also showed the importance of vanadium in mixed Mo- $\mathrm{V}-\mathrm{Sb}-\mathrm{Nb}-\mathrm{O}$ system for propane ammoxidation. In their research, it was shown that a bulk $\mathrm{SbVO}_{4}$ oxide, containing traces of $\mathrm{V}_{2} \mathrm{O}_{5}$ crystals is capable to produce higher yield of acrylonitrile as compared to the reported result previously (Guerrero-Perez et al. 2004). Naraschewski et al. (2011a) studied the different vanadium, $\mathrm{V}$ content $(0.07,0.14$, and 0.22 ) and the results showed that the activity of the catalysts increasing with the increasing of $\mathrm{V}$ content hence proved that $\mathrm{V}$ is the key element for propane oxidation.

Therefore, this work proposed to investigate the influence of different vanadium sources on the characteristics of MoVTeNbOx catalysts. Three sources of vanadium were used which are vanadium pentoxide $\left(\mathrm{V}_{2} \mathrm{O}_{5}\right)$, vanadyl sulphate $\left(\mathrm{VOSO}_{4}\right)$ and ammonium metavanadate $\left(\mathrm{NH}_{4} \mathrm{VO}_{3}\right)$. The catalysts were prepared by using a slurry method assisted with microwave irradiation.

\section{Materials AND Methods}

\section{CATALYST PREPARATION}

$\mathrm{MoV}_{0.3} \mathrm{Te}_{0.23} \mathrm{Nb}_{0.12} \mathrm{O}_{\mathrm{x}}$ catalysts were prepared by microwave-assisted slurry method according to the patented procedure (Irmawati et al. 2016). The following chemicals were used: Ammonium heptamolybdate, $\left(\mathrm{NH}_{4}\right)_{6} \mathrm{Mo}_{7} \mathrm{O}_{24} \cdot 4 \mathrm{H}_{2} \mathrm{O}$ (Merck) with purity $99.3 \%$, ammonium metavanadate, $\mathrm{NH}_{4} \mathrm{VO}_{3}$ (Merck) with purity $96.0 \%$, telluric acid, $\mathrm{H}_{6} \mathrm{TeO}_{6}$ (Sigma-Aldrich) with purity $99.0 \%$, and ammonium niobium oxalate, $\left(\mathrm{NH}_{4}\right)_{2} \mathrm{Nb}_{2}\left(\mathrm{C}_{2} \mathrm{O}_{4}\right)_{5}$ (Aldrich) with purity $99.9 \%$ as the sources of $\mathrm{Mo}, \mathrm{V}$, Te and $\mathrm{Nb}$, respectively. A desired amount of deionized water was used to dissolve the chemical salts. Orange slurry that was obtained was rotary evaporated to remove the solvent. The precursor was later ground before calcination at $553 \mathrm{~K}$ in air and $873 \mathrm{~K}$ in a nitrogen stream. The calcined catalyst was then washed with $30 \%(\mathrm{w} / \mathrm{w})$ hydrogen peroxide to remove the inactive M2 phase, by stirring the solid catalyst in hydrogen peroxide for $3 \mathrm{~h}$ at a ratio of $1 \mathrm{~g}$ of catalyst to $10 \mathrm{~cm}^{3}$ of hydrogen peroxide. The solid was filtered and dried in an oven for overnight at $353 \mathrm{~K}$. All of the preparation steps were repeated with the other vanadium sources; vanadium pentoxide, $\mathrm{V}_{2} \mathrm{O}_{5}$ (Fluka Chemical) with purity $\geq 98.0 \%$ and vanadyl sulphate, $\operatorname{VOSO}_{4}$ (Sigma-Aldrich) with purity $97.0 \%$. The obtained MoVTeNb catalysts were then labeled as MVTN-VO, MVTN-VS, and MVTN-AMV in reference to the different vanadium sources of $\mathrm{V}_{2} \mathrm{O}_{5}$, $\mathrm{VOSO}_{4}$, and $\mathrm{NH}_{4} \mathrm{VO}_{3}$.

\section{CATALYST CHARACTERIZATIONS}

$\mathrm{X}$-ray powder diffraction patterns were recorded using a Shimadzu XRD 6000 diffractometry and $\mathrm{Cu} \mathrm{K}$ radiation with $2 \theta$ steps over the angular range $2-60^{\circ}$. The identity of the catalyst was obtained by comparing the diffraction lines and their intensities with a large data bank from Joint Committee on Powder Diffraction Standards (JCPDS). The specific surface area of the catalysts was determined by using BELSorp Mini II. 0.2- $0.5 \mathrm{~g}$ of 
catalysts was degassed prior to analysis. The surface area of the catalysts was measured by calculating the amount of adsorbed nitrogen based on Brunnauer-EmmettTeller (BET) method. The elemental compositions of the catalysts were determined by inductively coupled plasma atomic-emission spectrometry (ICP-AES). Temperature Programmed Reduction in Hydrogen $\left(\mathrm{H}_{2}-\mathrm{TPR}\right)$ was carried out by using Thermo Finnigan TPDRO 1100 Series. Prior to the analysis, the catalysts were pre-treated in a flow of nitrogen gas at $423 \mathrm{~K}$ at $20 \mathrm{~cm}^{3} \mathrm{~min}^{-1}$ flow rate for half an hour. The pretreated catalysts were subjected to a flow of $5 \%$ hydrogen in argon at constant temperature rate of $10 \mathrm{~K} \mathrm{~min}^{-1}$ from $323 \mathrm{~K}$ up to $1223 \mathrm{~K}$ for analysis.

Anaerobic Temperature Programmed Reaction was done by flowing propane/helium mixed stream (5\% propane, $1 \mathrm{bar}$, and $10 \mathrm{~cm}^{3} \mathrm{~min}^{-1}$ ) as the temperature was increased from $323 \mathrm{~K}$ to $1223 \mathrm{~K}$ at a heating rate of $10 \mathrm{~K} \mathrm{~min}$. The system was coupled with a mass spectrometry which is capable of monitoring multiple masses continuously to detect the output gas by recording propane $(\mathrm{m} / \mathrm{z}=29)$, propene $(\mathrm{m} / \mathrm{z}=41)$, acrolein $(\mathrm{m} / \mathrm{z}=56)$, acrylic acid $(\mathrm{m} / \mathrm{z}=72)$ and carbon dioxide $(\mathrm{m} / \mathrm{z}=44)$.
Before the analysis, the catalysts were pretreated in a flow of nitrogen at $25 \mathrm{~cm}^{3} \mathrm{~min}^{-1}$ for half an hour.

\section{RESULTS AND DisCUSSION}

\section{X-RAY DIFFRACTION ANALYSIS}

Figure 1 shows the XRD patterns of all catalysts which demonstrate similar diffraction patterns comprises of four main crystalline phases which are orthorhombic (M1) phase at $2 \theta=6.6,7.9,9.0,22.1,45.0^{\circ}$ (JCPDS: 58-790), hexagonal (M2) phase at $2 \theta=22.1,28.1,36.3,45.0,50.0^{\circ}$ (JCPDS: 57-1099), monoclinic, $\mathrm{TeMo}_{5} \mathrm{O}_{16}$ phase at $2 \theta=$ $8.9^{\circ}$ (JCPDS: $\left.31-0874\right)$ and tetragonal, $\left(\mathrm{V}_{0.07} \mathrm{Mo}_{0.93}\right)_{5} \mathrm{O}_{14}$ phase at $2 \theta=22.1,23.4,24.9,31.5^{\circ}$ (JCPDS: 31-1437). It should be noted that there is a peak shifting of MVTNAMV at $2 \theta=22.1$ towards higher angle. This might be correlated to the increase in crystallite size of the catalyst as evidenced in Table 2 in which the crystallite size of MVTN-AMV is larger than MVTN-VO and MVTN-VS, due to the change in the phase composition of the catalyst (Bakiro et al. 2019) caused by particle aggregation followed by crystal growth after washing treatment with $\mathrm{H}_{2} \mathrm{O}_{2}$.

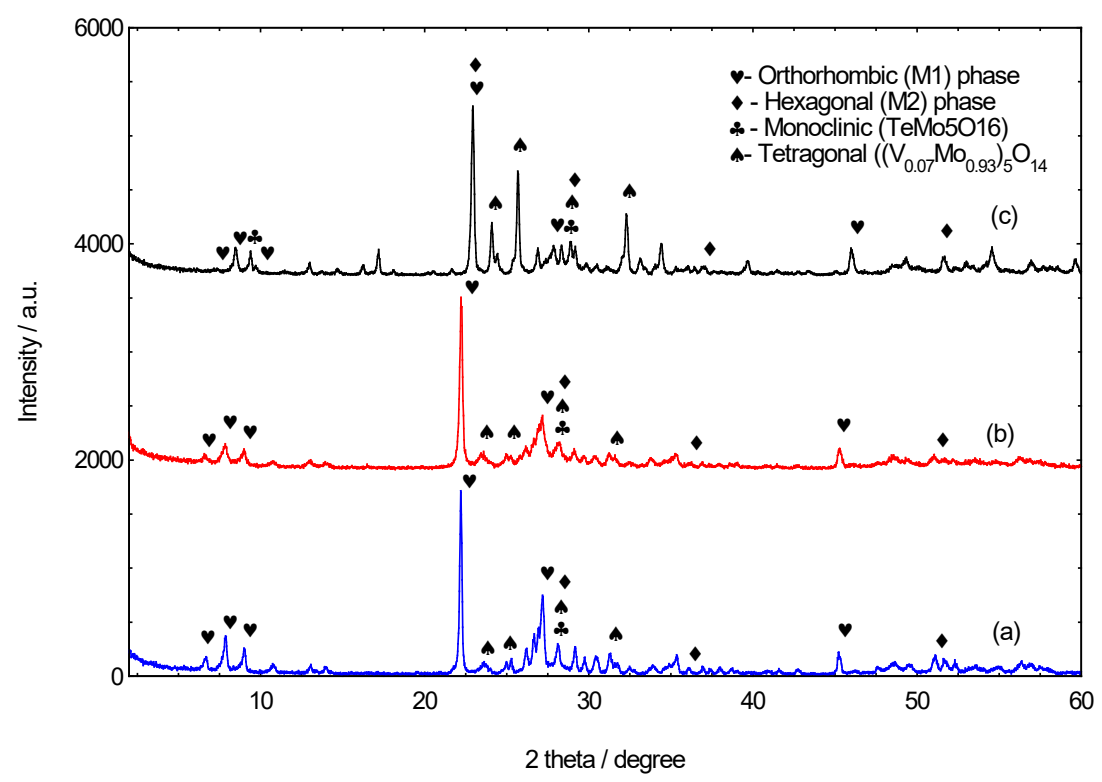

FIGURE 1. XRD patterns of MoVTeNb mixed oxide catalysts (a) MVTN-VO, (b) MVTN-VS, (c) MVTN-AMV 
The development of other phase such as tetragonal phase was observed due to hydroxylation process which is the introduction of hydroxyl group into the catalyst. According to Deniau et al. (2008), this hydroxylation process is the reaction between the solid and $\mathrm{H}_{2} \mathrm{O}_{2}$ (1) which would occur in the heptagonal channel into where the diffusion of $\mathrm{H}_{2} \mathrm{O}_{2}$ molecules may occur.

$$
\mathrm{M}-\mathrm{O}-\mathrm{Mb}_{\mathrm{b}}+\mathrm{H}_{2} \mathrm{O}_{2} \rightarrow \mathrm{M}_{\mathrm{a}}-\mathrm{OH}+\mathrm{M}_{\mathrm{b}}-\mathrm{OH}+1 / 2 \mathrm{O}_{2}
$$

The $\mathrm{M}_{\mathrm{a}}$ and $\mathrm{M}_{\mathrm{b}}$ correspond to neighboring metal cations lining the heptagonal channel. This process may induce stresses in the structure resulting to the structural modification from hexagonal to another phase such as tetragonal phase (Deniau et al. 2008). In the monoclinic phase, Botella et al. (2002) reported that the deep reduction has occurred during calcinations that can represented by $\left(\mathrm{Te}^{6+} \rightarrow \mathrm{Te}^{4+}\right.$ or $\left.\mathrm{V}^{5+} \rightarrow \mathrm{V}^{4+/ 3+}\right)$ which react with $\mathrm{MoO}_{3}$ to form the phase. The highly intense and sharp peaks demonstrate that the catalysts are crystalline, indicating a proper arrangement of atoms. Additionally, the well-developed orthorhombic (M1) phase could be observed in every catalyst, indicating that it is highly stable even after washing.

In order to investigate the effect of using different vanadium source on the phase formation, the composition of orthorhombic $(\mathrm{O})$, hexagonal $(\mathrm{H})$, monoclinic $(\mathrm{M})$ and tetragonal (T) was determined using (2), (3), (4), and (5), respectively. The main diffraction peaks at $2 \theta$ of $7.9^{\circ}$ for orthorhombic, $36.3^{\circ}$ for hexagonal, $8.9^{\circ}$ for monoclinic, and $31.5^{\circ}$ for tetragonal were used for the calculation. These peaks were chosen since they are devoted to the stated phase at that range. The phase composition was estimated by using the relative peak intensity (I) for each main diffraction peaks for all phases involved.

$$
\begin{array}{r}
\mathrm{O} \%=\left(\frac{\mathrm{I}_{\mathrm{O}}}{\mathrm{I}_{\mathrm{H}^{+}+\mathrm{I}_{\mathrm{T}}+\mathrm{I}_{\mathrm{M}}+\mathrm{I}_{\mathrm{O}}}}\right) \times 100 \\
\mathrm{H} \%=\left[\frac{1}{\left(\frac{\mathrm{I}^{+1} \mathrm{~T}^{+\mathrm{I}+\mathrm{I}} \mathrm{O}}{\mathrm{I}_{\mathrm{H}}}\right)}\right] \times 100
\end{array}
$$

$$
\begin{aligned}
& \mathrm{T} \%=\left[\frac{1}{\left(\frac{\mathrm{I}^{+1} \mathrm{~T}^{+\mathrm{I}^{+1} \mathrm{O}}}{\mathrm{I}_{\mathrm{T}}}\right)}\right] \times 100 \\
& \mathrm{M} \%=\left[\frac{1}{\left(\frac{\left.{ }^{\mathrm{I}_{\mathrm{I}} \mathrm{T}^{+\mathrm{I}} \mathrm{M}^{+\mathrm{I} O}}\right)}{\mathrm{I}_{\mathrm{M}}}\right)}\right] \times 100
\end{aligned}
$$

Table 1 shows the phase compositions of orthorhombic, hexagonal, monoclinic and tetragonal in the catalysts. MVTN-VO demonstrates the highest orthorhombic (active phase) composition which is $73.5 \%$ as compared to MVTN-VS (25.2\%) and MVTNAMV (26.4\%). The difference in relative intensity of the orthorhombic phase for each catalyst can be clearly observed from the XRD pattern and it is noteworthy that intensity of orthorhombic diffraction peak for MVTN-VO is much higher as compared to other catalysts. This higher intensity contributes towards higher phase compositions in the catalyst. The presence of low active phase in MVTN-VS and MVTN-AMV is due to the existence of rich tetragonal phase in MVTN-VS and of hexagonal and monoclinic phases in MVTN-AMV. These phases have been reported to be inactive for propane activation (Naraschewski et al. 2011a).

TABLE 1. Composition of phases of MVTN-VO, MVTN-VS and MVTN-AMV

\begin{tabular}{lcccc}
\hline \multicolumn{1}{r}{ Catalyst } & $\begin{array}{c}\text { Orthorhombic } \\
\text { O }(\%)\end{array}$ & $\begin{array}{c}\text { Hexagonal } \\
\text { H }(\%)\end{array}$ & $\begin{array}{c}\text { Monoclinic } \\
\text { M (\%) }\end{array}$ & $\begin{array}{c}\text { Tetragonal } \\
\text { T }(\%)\end{array}$ \\
\hline MVTN-VO & 73.5 & 6.8 & $*$ n.a. & 19.7 \\
MVTN-VS & 25.2 & 18.7 & *n.a. & 56.1 \\
MVTN-AMV & 26.4 & 27.5 & 27.5 & 18.7 \\
\hline
\end{tabular}

*n.a.: not applicable 
CRYSTALLITE SIZE (T), BET SURFACE AREA ( $\left.\mathrm{S}_{\mathrm{BET}}\right)$ AND ELEMENTAL COMPOSITION ANALYSES

Table 2 shows the effect of different source of vanadium on the crystallite size $(\mathrm{t})$, catalyst BET surface area $\left(\mathrm{S}_{\mathrm{BET}}\right)$ and its elemental composition. Crystallite size of the catalysts was determined from the XRD diffractograms using Scherrer equation as shown in (6). The data was calculated based on peaks intensity obtained from XRD patterns.

$$
t=0.9 \lambda /(\beta \operatorname{Cos} \theta)
$$

where $\beta$ is full width at half maximum (FWHM) at ( $h k l)$ peak in radian unit; $\lambda$ is wavelength of XRD for $\mathrm{Cu} \mathrm{K}$ and $\theta$ is the Bragg angle. The diffraction peaks chosen was $2 \theta$ $=6.6,7.9,9.0,22.1,45.0^{\circ}$ which are orthorhombic $(\mathrm{M} 1)$ phase peaks.

As listed in Table 2, MVTN-VS demonstrates the lowest crystallite size as compared to MVTN-VO and
MVTN-AMV. The larger in crystallite size for MVTN-VO and MVTN-AMV might be due to particle aggregation followed by crystal growth after washing treatment with $\mathrm{H}_{2} \mathrm{O}_{2}$. The particles become embedded together without separate properly, thus, contribute towards larger particle size. Generally, it is stated that a higher surface area corresponding to smaller particle size (Florea et al. 2006). However, in this work the surface area value not related to crystallite size due to the nature of the catalysts which are in mixed phases. As summarized in Table 2, despite its larger crystallite size, MVTN-AMV shows the highest $\mathrm{S}_{\mathrm{BET}}$ value, followed by MVTN-VS and MVTNVO. Therefore, crystallite size calculated using Scherrer equation might not represent the actual size of the catalysts. One important note here is the higher surface area may not contribute to higher catalytic activity because the activity and selectivity of the catalyst also depend on the active phase of the catalysts.

TABLE 2. Crystallite size, BET specific surface area, and elemental composition of MVTN-VO, MVTN-VS and MVTN-AMV catalysts

\begin{tabular}{lcccc}
\hline \multicolumn{1}{c}{ Catalyst } & $\mathrm{t}(\mathrm{nm})^{1}$ & $\begin{array}{c}\mathrm{S}_{\mathrm{BET}} \\
\left(\mathrm{m}^{2} \mathrm{~g}^{-1}\right)\end{array}$ & $\begin{array}{c}\text { Elemental composition }{ }^{2} \text { (bulk) } \\
\text { Mo:V:Te:Nb }\end{array}$ & $\begin{array}{c}\text { Mole fraction } \\
\text { V:Mo }\end{array}$ \\
\hline MVTN-VO & 50.5 & 6.8 & $1.0: 0.21: 0.04: 0.10$ & 0.21 \\
MVTN-VS & 36.4 & 17.0 & $1.0: 0.12: 0.02: 0.17$ & 0.12 \\
MVTN-AMV & 54.9 & 19.2 & $1.0: 0.08: 0.02: 0.12$ & 0.08 \\
\hline
\end{tabular}

Theoretical molar ratio of Mo:V:Te: $\mathrm{Nb}=1: 0.3: 0.23: 0.12 ;{ }^{1}$ Determined by Scherrer equation;

${ }^{2}$ Elemental composition as determined by ICP-AES

However, vanadium pentoxide shows a pronounced effect on the elemental composition of the catalysts. This is because highest vanadium content is found in MVTNVO with V: Mo ratio of 0.21. MVTN-VS and MVTN-AMV had a V: Mo ratio of only 0.12 and 0.08 , respectively. Naraschewski et al. (2011b) reported that the formation of $\mathrm{M} 1$ phase requires $\mathrm{V}$ : Mo ratios higher than 0.14 while lower concentration of $\mathrm{V}$ only contribute to other phases.
It can be seen that MVTN-VO, which has a V: Mo ratio of more than 0.14 produces the higher presence of M1 phase as evidenced in XRD. Nonetheless, this value (V: Mo = 0.21 ) is a reduced quantity as opposed to the intended $\mathrm{V}$ : Mo ratio of 0.3 . Hence, the lower concentration of $\mathrm{V}$ only contributes to the presence of other phases such as hexagonal and tetragonal in MVTN-VO and hexagonal, tetragonal and monoclinic in MVTN-VS and MVTNAMV. 
Meanwhile, all catalysts demonstrate a drastic reduction of Te element. This might be due to the elimination of hexagonal (M2) phase containing rich Te content after washing process (Grasselli et al. 2008). Hexagonal (M2) phase is known to have high content of Te element because it serves as a Te reservoir (Baca et al. 2003). Washing with peroxide efficiently removes the inactive hexagonal (M2) phase. The hexagonal phase is believed to be distorted into the monoclinic phase due to the leaching of Te from the bulk catalyst as the result of washing with $\mathrm{H}_{2} \mathrm{O}_{2}$ (Deniau et al. 2008). The depletion of Te in all of the catalysts is in a good agreement with XRD results as evidenced by the low levels of the hexagonal phase. Similarly, minimal quantities of $\mathrm{Nb}$ are needed and its presence is not pertinent to the formation of the orthorhombic M1 phase.

\section{TEMPERATURE PROGRAMMED REDUCTION IN HYDROGEN $\left(\mathrm{H}_{2}-\mathrm{TPR}\right)$}

$\mathrm{H}_{2}$-TPR was used to study the reducibility of the catalysts by flowing hydrogen gas over the catalyst and see the evolution of water as a product. The interaction between the gas phase hydrogen with oxygen from the catalyst can be represented as below:

$$
\mathrm{H}_{2(\mathrm{~g})}+\mathrm{O}_{2(\mathrm{~s}, \mathrm{l})} \rightarrow \mathrm{H}_{2} \mathrm{O}_{(\mathrm{g})}+\bullet
$$

where (g), (s), (1) denotes gaseous, surface, lattice species whereas - denotes oxygen vacancy.

The formation of water as the product leaves a vacancy on the surface of the catalyst when oxygen was taken by hydrogen during high temperature reaction. Figure 2 depicts the $\mathrm{H}_{2}$-TPR profiles for all catalysts.

The reduction profiles show an evolution of two overlapping peaks maxima at $926 \mathrm{~K}$ and $1015 \mathrm{~K}$ for MVTN-VO and 830 and $1111 \mathrm{~K}$ for MVTN-VS. Meanwhile, three overlapping peaks maxima are observed at 825 , 877 , and $1060 \mathrm{~K}$ for MVTN-AMV. This phenomenon is possibly due to the successive steps of metal oxide reduction in the multicomponent catalysts. Reduction of $\mathrm{MoO}_{\mathrm{n}}\left(\mathrm{Mo}^{6+} \rightarrow \mathrm{Mo}^{4+}\right.$ and $\left.\mathrm{Mo}^{4+} \rightarrow \mathrm{Mo}^{0}\right)$ occurs at 948 and $995 \mathrm{~K}$ (Wong et al. 2012), $\mathrm{VO}_{\mathrm{n}}$ reduced at 913 and $943 \mathrm{~K}\left(\mathrm{~V}^{5+} \rightarrow \mathrm{V}^{4+}\right.$ and $\left.\mathrm{V}^{4+} \rightarrow \mathrm{V}^{0}\right)$ and $\mathrm{Nb}$ reduced at $1243 \mathrm{~K}\left(\mathrm{Nb}^{5+} \rightarrow \mathrm{Nb}^{4+}\right.$ ) (Pereira et al. 2000). The multiple reductions reckon that the catalysts have a kinetically different oxygen species. The facts that the reduction occurs at a very high temperatures (above $600 \mathrm{~K}$ ) indicates that the oxygen which were removed during the reduction reaction are strongly adsorbed oxygen species that might be originated from surface and lattice of the catalysts (Lin 2001; Ueda et al. 2004). This can be confirmed by calculating the reduction activation energy, $\mathrm{E}_{\mathrm{r}}$ using a Redhead equation as shown:

$$
-\frac{\left[E_{\mathrm{r}}\right]}{\mathrm{RT}_{\mathrm{m}}{ }^{2}}=\left[\mathrm{H}_{2}\right]_{\mathrm{m}}\left(\frac{\mathrm{A}}{\beta}\right) \exp \frac{-\mathrm{E}_{\mathrm{r}}}{\mathrm{RT}_{\mathrm{m}}}
$$

where $T_{m}$ is the peak maximum temperature $(K)$ in the rate consumption of $\mathrm{H}_{2} ; \mathrm{E}_{\mathrm{r}}$ is the reduction activation energy $\left(\mathrm{kJ} \mathrm{mol}^{-1}\right)$. Meanwhile $\mathrm{A}$ is the reduction preexponential term $\left(\mathrm{cm}^{3} \mathrm{~mol}^{-1} \mathrm{~s}^{-1}\right)$ which gives the value of standard collision number of $10^{13} \mathrm{~cm}^{3} \mathrm{~mol}^{-1} \mathrm{~s}^{-1}$ and is the gas phase concentration of hydrogen $\left(\mathrm{mol} \mathrm{cm}^{-3}\right)$ at the peak maximum.

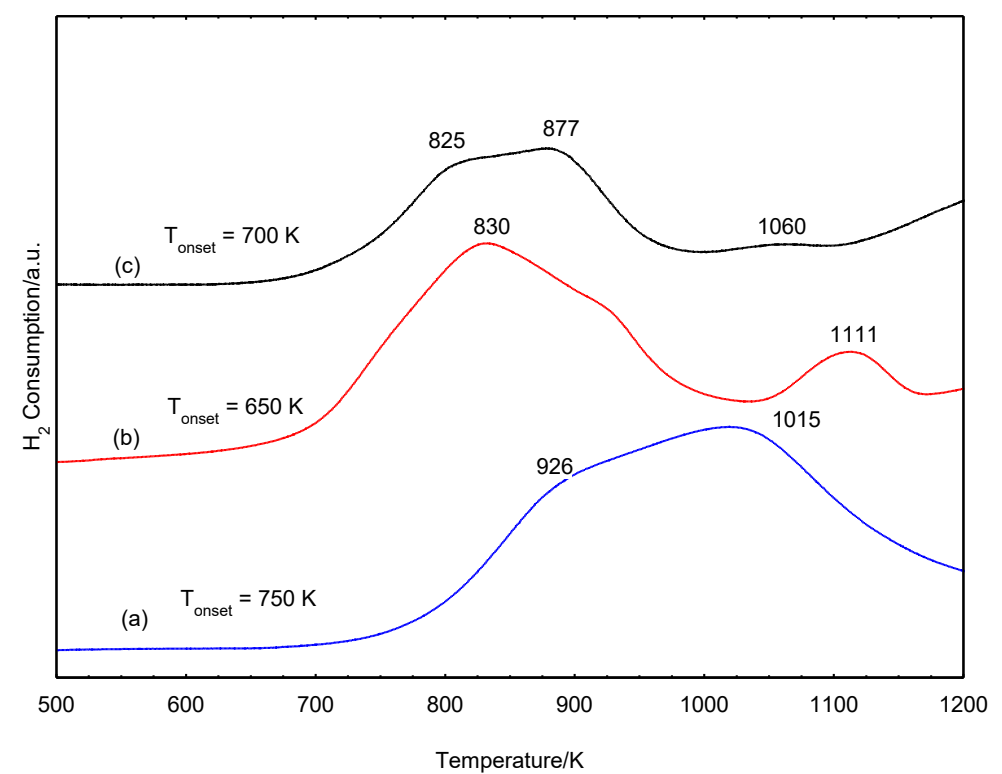

FIGURE 2. $\mathrm{H}_{2}$-TPR profiles of MoVTeNb mixed oxide (a) MVTN-VO, (b) MVTN-VS (c) MVTN-AMV 
The $\mathrm{E}_{\mathrm{r}}$ values for all the catalysts are above $100 \mathrm{~kJ}$ $\mathrm{mol}^{-1}$ signifying the oxygen are strongly bonded to the catalyst. The amount of oxygen removed was determined by calculating the area under the peak and its value is listed in Table 3. It is found that the amount of oxygen removed for all catalysts exceeded $1.0 \times 10^{15}$ atom $\mathrm{g}^{-1}$, which is a monolayer value of surface species according to Arrhenius. Hence, the oxygen that was removed in this work is originated from the surface and lattice of the catalyst, in accordance with the high reduction activation energy, $\mathrm{E}_{\mathrm{r}}$ as discussed earlier (Woi et al. 2007). Therefore, all of the catalysts synthesized in this work are highly reducible at high reduction temperature and the oxygen could be active oxygen that is required to be inserted in the reactant molecules.

Among the catalysts, MVTN-VS has the lowest onset temperature which is $650 \mathrm{~K}$ compared to MVTN-VO and MVTN-AMV with onset temperature of $750 \mathrm{~K}$ and $700 \mathrm{~K}$, respectively. The removal of oxygen species at lower temperature certainly gives better catalytic activity of the catalysts. Although MVTN-VS and MVTN-AMV exhibit much lower onset temperature than MVTN-VO which indicates the easily removed of oxygen species, it could be due to the unselective oxygen species caused by the presence of rich non-active phases in both catalysts. As presented in Table 3, among the catalysts under investigation, the highest total of oxygen removed occurs for MVTN-VO, suggesting the higher activity of the catalyst. This would be ascribed to the highest composition of active orthorhombic M1 phase of MVTN$\mathrm{VO}$ that is responsible to facilitate the oxygen removable (Wong et al. 2016).

TABLE 3. Summary of data from $\mathrm{H}_{2}$-TPR of MVTN-VO, MVTN-VS and MVTN-AMV

\begin{tabular}{|c|c|c|c|c|}
\hline $\begin{array}{l}\text { Type of } \\
\text { catalysts }\end{array}$ & $\mathrm{T}_{\max }(\mathrm{K})$ & $\begin{array}{l}\text { Reduction activation energy, } \mathrm{E}_{\mathrm{r}}(\mathrm{kJ} \\
\left.\mathrm{mol}^{-1}\right)\end{array}$ & $\begin{array}{l}\text { Oxygen removed (mol } \\
\left.\qquad \mathrm{g}^{-1}\right)\end{array}$ & $\begin{array}{l}\text { Oxygen removed (atom } \\
\left.\qquad \mathrm{g}^{-1}\right)\end{array}$ \\
\hline \multirow[t]{2}{*}{ MVTN-VO } & 926 & 154.85 & $0.44 \times 10^{-2}$ & $0.27 \times 10^{22}$ \\
\hline & 1015 & 169.74 & $3.25 \times 10^{-2}$ & $1.96 \times 10^{22}$ \\
\hline \multirow[t]{2}{*}{ MVTN-VS } & 830 & 138.80 & $2.28 \times 10^{-2}$ & $1.37 \times 10^{22}$ \\
\hline & 1111 & 185.79 & $0.26 \times 10^{-2}$ & $0.16 \times 10^{22}$ \\
\hline \multirow{3}{*}{ MVTN-AMV } & 825 & 137.96 & $0.32 \times 10^{-2}$ & $0.19 \times 10^{22}$ \\
\hline & 877 & 146.67 & $1.30 \times 10^{-2}$ & $0.78 \times 10^{22}$ \\
\hline & 1060 & 177.26 & $0.03 \times 10^{-2}$ & $0.02 \times 10^{22}$ \\
\hline
\end{tabular}

\section{CATALYTIC PERFORMANCE}

The catalytic performance of the MoVTeNb oxide catalysts were evaluated for selective oxidation of propane to acrylic acid by using Temperature Programmed Reaction (TPRn). This is an anaerobic propane oxidation reaction over MoVTeNbOx catalyst. The catalytic response obtained in the form of a mass spectrogram of respective $\mathrm{m} / \mathrm{z}$ was analysed quantitatively. As illustrated in Figure 3, the TPRn profiles is just focusing on MVTN-VO because of the better characteristics and physicochemical properties that have been discussed earlier. It was found that from room temperature up to $750 \mathrm{~K}$, there is an adsorption of propane molecule on the catalyst surface as indicated by the downward shape of the 
propane's curve. The adsorbed propane was later desorbed as propane molecules. However, some of the adsorbed propane undergone a carbon-carbon (C-C) bond breakage to form carbon dioxide $\left(\mathrm{CO}_{2}\right)$ as early as $700 \mathrm{~K}$. The $\mathrm{C}-\mathrm{C}$ bond breakage happened when adsorbed propane reacts with surface oxygen which already present on the catalyst. The peak maximum for $\mathrm{CO}_{2}$ production is at $750 \mathrm{~K}$.

Propene started to be evolved at temperature around 790 until $950 \mathrm{~K}$, coincide with propane desorption profile demonstrating a dehydrogenation of propane to form propene. The formation of acrolein (2-propenal) can only be observed much later at temperature of $930 \mathrm{~K}$. The peak maximum for acrolein production is $950 \mathrm{~K}$. The evolution of acrolein is coincided with the peak evolution of acrylic acid which is found started to be evolved at the same temperature with acrolein with peak maximum at $1400 \mathrm{~K}$. This occurrence suggested that the adsorbed propane undergone a surface reaction to form propene which eventually inserted oxygen from the lattice of the catalyst to form acrolein and in turn inserted another oxygen to form acrylic acid. The oxygen is proposed to be originated from the surface and lattice of the catalyst considering the fact that the reaction was done without oxygen flow.

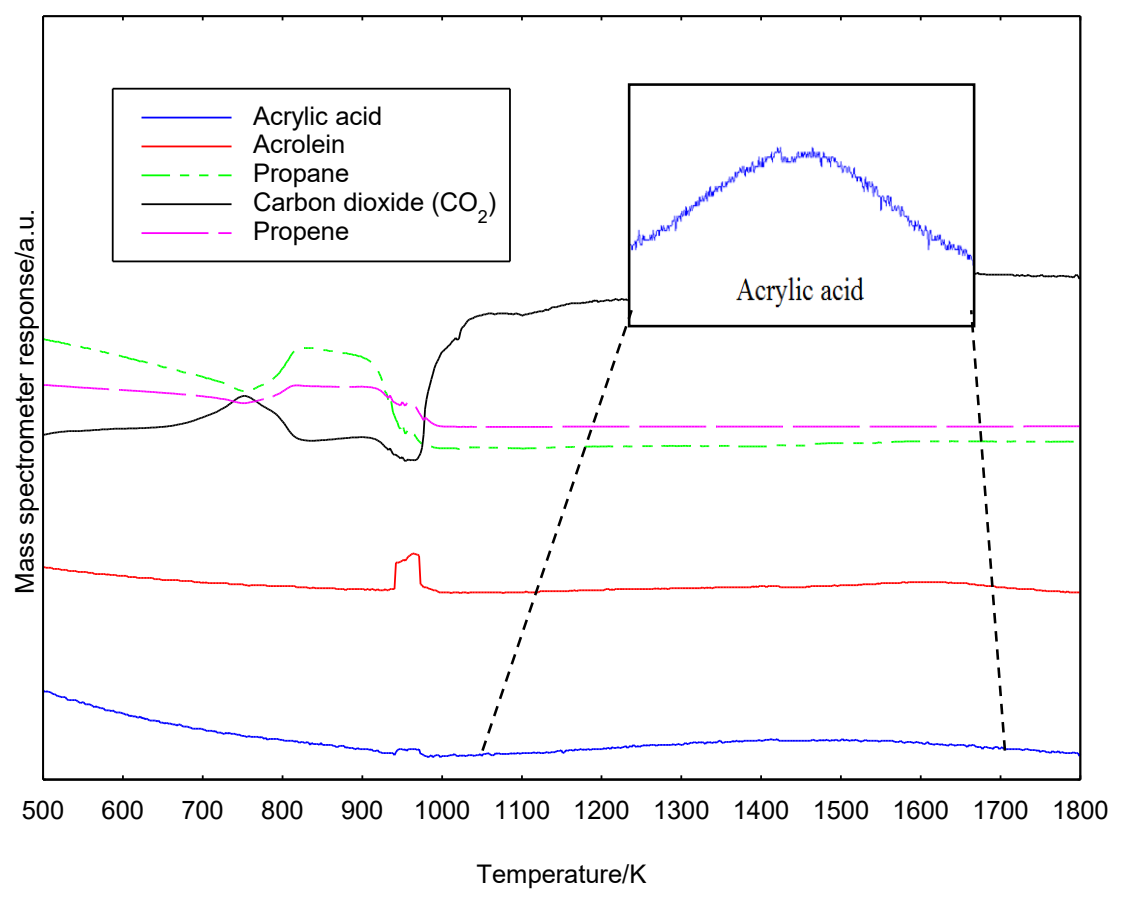

FIGURE 3. TPRn profiles of MVTN-VO

Additionally, the evolution of acrylic acid that occurs in the temperature range of $930-1700 \mathrm{~K}$ which is coincide with the oxygen reduction profiles observed in $\mathrm{H}_{2}$-TPR suggesting that the same oxygen was involved in the acrylic acid formation. Therefore, these oxygens are the selective ones for acrylic acid production. In addition to the acrylic acid selectivity, the production of acrylic acid also mainly attributable to the high composition of 
active orthorhombic phase of MVTN-VO (Table 1). The TPRn profile also shows a continuous production of $\mathrm{CO}_{2}$ due to total oxidation of some of propane. This cannot be avoided due to the nature of the reaction process itself that was done anaerobically. Other than that, the absence of steam or water in the feed of reactor becomes another main disadvantage of TPRn as compared to catalytic test. According to Recknagel and Riekert (1994), the catalyst works best when steam was presence during the reaction process to help oxidise the allylic intermediate that was formed into acrylic acid. Therefore, the absence of steam in the feed of reactor becomes main disadvantage of TPRn because the catalytic performance of the prepared catalysts decreases without the presence of the steam and the phase composition also changes (Novakova et al. 2002). Nevertheless, this TPRn analysis shed some lights of the importance of lattice oxygen in the selectivity of oxidation reaction of propane into acrylic acid.

It can be reckoned that the propane transformation into acrylic acid using the synthesized MoVTeNb mixed oxide catalysts occurred through the reaction pathway as shown in Figure 4.



FIGURE 4. Proposed reaction pathways of propane oxidation over $\mathrm{MoVTeNb}$ mixed oxide catalyst

\section{CONCLUSION}

In summary, using different vanadium sources have been shown to give a pronounced effect on the physicochemical properties of MoVTeNb mixed oxide catalysts. Vanadium pentoxide as V source is suggested to be used for the synthesis of MoVTeNbOx catalyst by using a slurry method assisted by microwave irradiation. This is because of the source gives the highest V: Mo ratio contributing to the formation of orthorhombic phase (M1) with high percentage. Reducibility study showed that the catalyst is highly reducible at high temperature and the oxygen removed are originated from the surface and lattice of the catalysts. Anaerobic oxidation of propane suggested a stepwise reaction of propane to form propene, acrolein and finally acrylic acid by using a surface and lattice oxygen for the reaction.

\section{ACKNOWLEDGEMENTS}

The authors would like to thank Universiti Putra Malaysia under Geran Penyelidikan Pembangunan Inovasi (GPPI/2019/9676400) for financial support.

\section{REFERENCES}

Al-Saeedi, J.N., Guliants, V.V., Guerrero-Perez, O. \& Banares, M.A. 2003. Bulk structure and catalytic properties of mixed 
$\mathrm{Mo}-\mathrm{V}-\mathrm{Sb}-\mathrm{Nb}$ oxides for selective propane oxidation to acrylic acid. Journal of Catalysis 215(1): 108-115.

Baca, M., Pigamo, A., Dubois, J.L. \& Millet, J.M.M. 2003. Propane oxidation on MoVTeNbO mixed oxide catalysts: Study of the phase composition of active and selective catalysts. Topics in Catalysis 23(1): 39-46.

Bakiro, M., Ahmed, S.H. \& Alzamly, A. 2019. Effect of pH, surfactant, and temperature on mixed-phase structure and band gap properties of $\mathrm{BiNbO}_{4}$ nanoparticles prepared using different routes. Chemistry 1: 89-110.

Beato, P., Blume, A., Girgsdies, F., Jentoft, R.E., Schlogl, R., Timpe, O., Trunschke, A., Weinberg, G., Basher, Q., Hamid, F.A., Hamid, S.B.A., Omar, E. \& Mohd Salim, L. 2006. Analysis of structural transformations during the synthesis of a MoVTeNb mixed oxide catalyst. Applied Catalysis A: General 307(1): 137-147.

Botella, P., Lopez-Nieto, J.M., Solsona, B., Mifsud, A. \& Marquez, F. 2002. The preparation, characterization, and catalytic behavior of MoVTeNbO catalysts prepared by hydrothermal synthesis. Journal of Catalysis 209(2): 445455.

Deniau, B., Millet, J.M.M., Loridant, S., Christin, N. \& Dubois, J.L. 2008. Effect of several cationic substitutions in the M1 active phase of the MoVTeNbO catalysts used for the oxidation of propane to acrylic acid. Journal of Catalysis 260(1): 30-36

Florea, M., Mamede, A.S., Eloy, P., Parvulescu, V.I. \& Gaigneaux, E.M. 2006. High surface area Mo-V-Te-Nb-O catalysts: Preparation, characterization and catalytic behaviour in ammoxidation of propane. Catalysis Today 112(1-4): 139-142.

Grasselli, R.K., Lugmair, C.G., Volpe Jr., A.F., Anderson, A. \& Burrington, J.D. 2008. Inhibition of propylene oxidation to acrylic acid by amorphous overlayers on $\mathrm{MoV}(\mathrm{Nb}) \mathrm{TeO}$ based M2 catalysts. Catalysis Letters 126(3): 231-240

Guerrero-Perez, M.O., Al-Saeedi, J.N., Guliants, V.V. \& Banares, M.A. 2004. Catalytic properties of mixed Mo$\mathrm{V}-\mathrm{Sb}-\mathrm{Nb}-\mathrm{O}$ oxides catalysts for the ammoxidation of propane to acrylonitrile. Applied Catalysis A: General 260(1): 93-99.

Irmawati, R., Muda, A.A., Ismail, A.Z. \& Ahangar, H.A. 2016. A Method for Synthesizing Multi-metal Oxide Catalyst. Malaysian Patent MY 156457.

Irmawati, R., Botella, P., Ivars, F., Wong, P.M., Zawawi, S.M.M., Ahangar, H.A., Hernandez, S. \& Nieto, J.M.L. 2011. Reflux method as a novel route for the synthesis of MoVTeNbOx catalysts for selective oxidation of propane to acrylic acid. Journal of Molecular Catalysis A: Chemical 342-343: 50-57.

Lin, M.M. 2001. Selective oxidation of propane to acrylic acid with molecular oxygen. Applied Catalysis A: General 207(12): 1-16.
Naraschewski, F.N., Jenthys, A. \& Lercher, J.A. 2011a. On the role of the vanadium distribution in $\mathrm{MoVTeNbO}_{\mathrm{x}}$ mixed oxides for the selective catalytic oxidation of propane. Topics in Catalysis 54(10-12): 639-649.

Naraschewski, F.N., Kumar, C.P., Jenthys, A. \& Lercher, J.A. 2011b. Phase formation and selective oxidation of propane over MoVTeNbOx catalysts with varying compositions. Applied Catalysis A: General 391(1-2): 63-69.

Novakova, E.K., Vedrine, J.C. \& Derouane, E.G. 2002. Effect of water on the partial oxidation of propane to acrylic and acetic acids on Mo-V-Sb-Nb mixed oxides. Catalysis Letters 83(3--4): 177-182.

Pereira, E.B., Pereira, M.M., Lam, Y.L., Perez, C.A.C. \& Schmal, M. 2000. Synthesis and characterization of niobium oxide layers on silica and the interaction with nickel. Applied Catalysis A: General 197(1): 99-106.

Popova, G.Y., Andrushkevich, T.V., Chesalov, Yu, A., Plyasova, L.M., Dovlitova, L.S., Ischenko, E.V., Aleshina, G.I. \& Khramov, M.I. 2009a. Formation of active phases in $\mathrm{MoVTeNb}$ oxide catalysts for ammoxidation of propane. Catalysis Today 144(3-4): 312-317.

Popova, G.Y., Andrushkevich, T.V., Dovlitova, L.S., Aleshina, G.A., Chesalov, Y.A., Ischenko, A.V., Ischenko, E.V., Plyasova, L.M., Malakhov, V.V. \& Khramov, M.I. 2009b. The investigation of chemical and phase composition of solid precursor of MoVTeNb oxide catalyst and its transformation during the thermal treatment. Applied Catalysis A: General 353(2): 249-257.

Recknagel, R. \& Riekert, L. 1994. Kinetik der katalytischen oxidation von acrolein zu acrylsäure. Chemical Technology 46(6): 324-330

Ueda, W., Vitry, D. \& Katou, T. 2004. Structural organization of catalytic functions in Mo-based oxides for propane selective oxidation. Catalysis Today 96(4): 235-240.

Woi, P.M., Irmawati, R. \& Taufiq-Yap, Y.H. 2007. Influence of organic species on the characteristics of Mo-V oxides. The Malaysian Journal of Analytical Sciences 11(1): 160-165.

Wong, H.R., Irmawati, R. \& Taufiq-Yap, Y.H. 2016. Enhanced reducibility of Mg-doped MoVTeNbOx mixed oxide catalysts for propane oxidation reaction. The Malaysian Journal of Analytical Sciences 20(6): 1299-1310.

Wong, M.S., Irmawati, R., Ahangar, H.A., Taufiq-Yap, Y.H., Tan, Y.P. \& Muhamad, E.N. 2012. Physicochemical studies of Ni-, Co-, Pt- promoted MoVNbOx catalysts synthesized by impregnation method. Oriental Journal of Chemistry 28(1): 59-65.

Haslinda Mohd Sidek, Irmawati Ramli* \& Taufiq-Yap Yun Hin Catalysis Science and Technology Research Centre (PutraCAT)

Faculty of Science

Universiti Putra Malaysia

43400 UPM Serdang, Selangor Darul Ehsan Malaysia 
Haslinda Mohd Sidek, Irmawati Ramli*, Norhazlin Zainuddin \& Taufiq-Yap Yun Hin

Department of Chemistry

Faculty of Science

Universiti Putra Malaysia

43400 UPM Serdang, Selangor Darul Ehsan

Malaysia

Hossein Abbastabar Ahangar

Department of Chemistry

Islamic Azad University

Najafabad Branch

85141-43131 Najafabad

Iran
Taufiq-Yap Yun Hin

Chancellery Office

Universiti Malaysia Sabah

88400 Kota Kinabalu, Sabah

Malaysia

*Corresponding author; email: irmawati@upm.edu.my

Received: 6 November 2020

Accepted: 30 December 2020 